Prespective and Implementative of The Basis of The Single Prosecution System of The Prosecution of The Prosecution Bill

\author{
Priandhika Abadi Noer ${ }^{1}$ \\ priandhikaabadi@gmail.com \\ ${ }^{1}$ Faculty of Law - Universitas Airlangga Surabaya
}

\begin{abstract}
Revision of Law no. 16 of 2004 concerning the Republic of Indonesia Attorney General's Office is a necessity because of the many changes that have occurred in the field. would replace Law no. 16 of 2004 is the right moment to encourage the Ago to do better. "Change is a necessity. Likewise in legislation, " ini this research concern about the duties and powers of the Prosecutor's Office in the draft law on the prosecutor's office. namely Guidelines on The Role of Prosecutors which serve as guidelines and inspire in the amendment of this Law, especially matters relating to independence in Prosecution, Accountability in Case Handling, Standards of Professionalism, and Protection for Prosecutors. If the Prosecution Bill becomes the new Prosecutor's Law, justice seekers will place the foundation of justice on the prosecutor, so that the prosecution process starting from investigation, investigation, prosecution and execution will optimally realize substantial truth and justice.
\end{abstract}

Keywords: Integrated criminal justice system, Criminal Procedure, The prosecutor's

\title{
Introduction
}

Integrated criminal justice system in law enforcement, the principle of functional differentiation that views these principles, the Criminal Procedure Code has laid down a principle as clarification and modification of functions and authorities between law enforcement agencies. By the degree of investigation up to the implementation of court decisions there is a continuous functional relationship with the existence of control between law enforcers in a series of integrated criminal justice systems.

The prosecutor's institution as a state institution in the judiciary or executive, protection of prosecutors, the authority of prosecutors in the criminal field (including discretionary prosecution based on the principle of restorative justice), in the civil and state administration, as well as other fields based on law. Of all these reforms, the prosecution has received a lot of 
attention, because in the bill, the prosecutor will be in control of the prosecution process starting from investigation, investigation, prosecution and execution. ${ }^{1}$

Revision of Law no. 16 of 2004 concerning the Republic of Indonesia Attorney General's Office is a necessity because of the many changes that have occurred in the field. During the Covid-19 pandemic there was a change in trial procedures after the online court system was accommodated. Not to mention the changes that have occurred to the Criminal Procedure Code, and the urgency to adopt a number of treaties or international conventions.

Attorney General, ST Burhanuddin, said the drafting of the Prosecutor's Bill, which would replace Law no. 16 of 2004 is the right moment to encourage the Ago to do better. "Change is a necessity. Likewise in legislation, " ini this research concern about the duties and powers of the Prosecutor's Office in the draft law on the prosecutor's office.

Through normative juridical research with the consideration that the starting point of research is analysis of statutory regulations in the Indonesian national legal framework, then the type of research used is normative juridical research, ${ }^{2}$ which is research focused on examining the application of the rules or norms of positive law, in particular. regarding the arrangement of duties of the RI Prosecutor's Office In this research using a statutory approach, a conceptual approach, a statute approach, the approach that the author takes is an approach to related laws, including Law number 16 of 2004 concerning the Attorney General's Office. ${ }^{3}$ Republic of Indonesia, Attorney General's Regulation No: PER-009 / A / JA / 01/2011 concerning the Organization and Work Procedure of the Republic of Indonesia Prosecutor's Office. problems such as general law principles

\section{Sub Title}

In the draft Law on the Prosecutor's Office, the authority to investigate prosecutors is issued in article 30 .

${ }^{1}$ https://kejari-nabire.go.id/tugas-dan-fungsi-perdata-dan-tun/

2 Peter Mahmud Marzuki, Penelitian Hukum, Kencana Prenada Media Group,Jakarta, 2005, page. 171

${ }^{3}$ Yudi Kristina, 2006, Independesi Kejaksaan Dalam Penyidikan Korupsi, Citra Aditya Bakti, Bandung, page 56 
(1) In the field of crime, the prosecutor's office has the duties and authorities:

a. carry out the prosecution process;

b. carry out judges' orders and court decisions that have resulted in permanent law;

c. to supervise the implementation of conditional criminal decisions, supervising criminal decisions and conditional release decisions, and to transfer the convicted person;

d. carry out investigations of criminal acts based on law;

e. certain case files by carrying out further investigations;

f. perform penal mediation;

g. carry out tracing, crime, confiscation and restoration of the state and criminal assets;

(2) In the criminal sector, the prosecutor's office has the duties and authorities:

carry out the prosecution process;

a. carry out judges' orders and court decisions that have permanent legal force;

b. to supervise the implementation of conditional criminal decisions, supervisory criminal decisions and conditional release decisions, as well as carry out transfers of the convicted person;

c. carry out investigations on certain crimes based on law;

d. complete certain case files by carrying out further investigations; f. perform penal mediation;

e. carry out tracing, tracking, confiscation and recovery of state assets and the acquisition of crimes;

f. (2) To complete the case file, further investigation is carried out with the following conditions:

g. committed against the suspect;

h. is carried out for cases which are difficult to prove, and / or which cause public disturbance, and / or which may endanger the safety of the state, and / or to speed up the settlement of cases;

i. completed within no later than 30 (thirty) days after the completion of the legal process as regulated in the statutory regulations in the field of criminal procedural law and can be extended not later than 30 (thirty) days. 
(3) Further provisions regarding Advanced Investigation as referred to in paragraph (2) shall be regulated in a Government Regulation.

(4) In the civil and state administration and state administration, the Attorney General Office with or without special powers acts as State Attorney, in all spheres of the judiciary and the Constitutional Court, both inside and outside the court for and on behalf of the state or the Government, as well as the interests general.

(5) In the field of public order and peace, the Attorney General's Office shall conduct investigations, safeguards and raise in support of law enforcement activities and policies which include:

a. authority as law enforcement intelligence;

b. increasing public legal awareness;

c. safeguarding law enforcement policies;

d. supervision of the circulation of printed and multimedia goods;

e. supervision of belief streams that can endanger the public and the state;

f. prevention of religious abuse and / or blasphemy;

g. wiretapping and running a monitoring center;

h. prevention of corruption, collusion and nepotism;

i. participate and contribute in conditions of the country in a state of danger, civil emergency, as well as military emergency, and a state of war.

(6) In addition to carrying out the duties and authorities as referred to in paragraph (1), paragraph (2), paragraph (3), and paragraph (4), the Attorney General's Office organizes research activities, legal development, criminal statistics, and judicial health of the Attorney General's Office., profession, and service.

In theory there is a single prosecution system principle. According to etymology, the word "prosecution" itself comes from Latin: prosecutus and consists of pro (before) and sequi (following) which can be understood as "the process of a case from beginning to end". In this case, the prosecutor handles the case from start to finish / execution. Thus, it 
is not surprising that prosecutors play an important role in determining the success of the law enforcement process in a country. ${ }^{4}$

In the criminal justice system in Indonesia, the position of the prosecutor is as a single prosecutor (single prosecution system) and as the only agency implementing criminal decisions (executive ambtenaar), ${ }^{5}$ which has been increasingly neglected in its development. At present, there are several other institutions that also carry out prosecution and execution functions but are not controlled by the Attorney General. ${ }^{6}$ For example, corruption cases were carried out by the Corruption Eradication Commission (KPK) and against perpetrators of criminal acts within the military justice environment which were carried out by military prosecutors, high military prosecutors and Indonesian National Armed Forces (TNI) prosecutors.

\section{Conclusion}

The commitment of the international community regarding the importance of strengthening the role of prosecutors in the function of law enforcement is manifested in the United Nations Guidelines on the Role of Prosecutors. As adopted at the 8th Congress for the Prevention of Crime, in Havana in 1990. Article 11 of the UN Guidelines on the Role of Prosecutors states that prosecutors must play an active role in the process of handling criminal cases, including prosecuting. The phrase "the prosecutor carries out the prosecution" must be interpreted as an implementation of the principle of a single prosecution system in the criminal justice system.

As part of the global community, Indonesia has also ratified Conventions such as the United Nations Against Transnational Organized Crime (UNTOC), the United Nations Conventions Against Corruption (UNCAC) which was ratified by Indonesia where Indonesia must carry out the norms in the Convention as compliance. . The new existing norms also affect the authority, duties and functions of the Attorney General's Office. As a member of the United Nations, Indonesia must also comply with the norms made by the United Nations in several of

${ }^{4}$ Barda Nawawi Arief Beberapa Aspek Kebijakan Penegakan Hukum dan Pengembangan Hukum Pidana, Citra Aditya Bakti, Bandung 2005, page 22

5 Andi Hamzah, 2008, Pemberantasan Korupsi melalui hukum pidana nasional dan internasional, Rajawali Pers, Jakarta , page. 16

${ }^{6}$ Erdianto Efendi, 2011, Hukum Pidana Indonesia - Suatu Pengantar, Refika Aditama, Bandung, page. 67 
its provisions. In 2014, the United Nations Office on Drugs and Crime (UNODC) and the International Association of Prosecutors (IAP), which the Attorney Office joined in 2006, issued the Status and Role of Prosecutors, as stated in the previous provisions, namely Guidelines on The Role of Prosecutors which serve as guidelines and inspire in the amendment of this Law, especially matters relating to independence in Prosecution, Accountability in Case Handling, Standards of Professionalism, and Protection for Prosecutors.

If the Prosecution Bill becomes the new Prosecutor's Law, justice seekers will place the foundation of justice on the prosecutor, so that the prosecution process starting from investigation, investigation, prosecution and execution will optimally realize substantial truth and justice.

\section{Bibliography}

\section{Books}

Achmad Ali, 2009, Menguak Teori Hukum (Legal Theory) dan Teori Peradilan (Judicialprudence) Termasuk Interpretasi Undang-Undang (Legisprudence), Kencana, Jakarta

Adam Chazawi, 2010, Pelajaran Hukum Pidana 1, Rajagrafindo Persada, Jakarta, Cetakan ke5

Andi Hamzah, 2008, Pemberantasan Korupsi melalui hukum pidana nasional dan internasional, Rajawali Pers, Jakarta

Chaerul Amir, 2014, Kejaksaan Memberantas Korupsi (Suatu Analisis : Historis, Sosiologis, dan Yuridis), PRO dealeader, Jakarta

Chairul Huda, 2013 Dari „Tiada Pidana Tanpa Kesalahan" menjadi kepada „Tiada Pertanggungjawaban Pidana Tanpa Kesalahan", Kencana, Jakarta

Erdianto Efendi, 2011, Hukum Pidana Indonesia - Suatu Pengantar, Refika Aditama, Bandung

Yudi Kristina, 2006, Independesi Kejaksaan Dalam Penyidikan Korupsi, Citra Aditya Bakti, Bandung

Act

1. Undang-Undang Nomor 31 Tahun 1999 tentang Pemberantasan Tindak Pidana Korupsi yang telah diubah dengan Undang-Undang Nomor 20 Tahun 2001 tentang Perubahan Atas Undang-Undang Nomor 31 Tahun 1999 tentang Pemberantasan Tindak Pidana Korupsi (Lembaran Negara Republik Indonesia 
Tahun 2001 Nomor 134, Tambahan Lembaran Negara Republik Indonesia Nomor 4150);

2. Undang-Undang Nomor 28 Tahun 1999 tentang Penyelenggaraan Negara yang Bersih dan Bebas dari Korupsi, Kolusi dan Nepotisme (Lembaran Negara Republik Indonesia Tahun 1999 Nomor 75, Tambahan Lembaran Negara Republik Indonesia Nomor 3851);

3. Undang-Undang Nomor 30 Tahun 2014 tentang Administrais Pemerintahan (Lembaran Negara Republik Indonesia Tahun 2014 Nomor 292, Tambahan Lembaran Negara Republik Indonesia Nomor 5601);

4. Undang-Undang Nomor 16 Tahun 2014 tentang Kejaksaan Republik Indonesia (Lembaran Negara Republik Indonesia Tahun 2004 Nomor 67, Tambahan Lembaran Negara Republik Indonesia Nomr 4401);

5. Peraturan Presiden Nomor 38 Tahun 2010 tentang Organisasi dan Tata Kerja Kejaksaan Republik Indonesia;

6. Peraturan Presiden Republik Indonesia Nomor 16 Tahun 2018 Tentang Pengadaan Barang dan Jasa Pemerintah Pemerintah;

7. Instruksi Presiden Nomor 7 Tahun 2015 tentang Aksi Pencegahan dan Pemberantasan Korupsi Tahun 2015;

8. Peraturan Jaksa Agung Republik Indonesia Nomor : PER-009/JA/01/2010 tentang Organisasi dan Tata Kerja Kejaksaan Republik Indonesia yang telah telah diubah dengan Peraturan Jaksa Agung Republik Indonesia Nomor PER006/A/JA/05/2014 tentang Perubahan atas Peraturan Jaksa Agung Republik Indonesia Nomor : PER-009/A/JA/01/2010 tentang Organisasi dan Tata Kerja Kejaksaan Republik Indonesia;

9. Keputusan Jaksa Agung Republik Indonesia Nomor : KEP-152/A/JA/10/2015 tentang Pembentukan Tim Pengawal dan Pengaman Pemerintahan dan Pembangunan Kejaksaan Republik Indonesia;

10. Instruksi Jaksa Agung Republik Indonesia Nomor : INS-001/A/JA/10/2015 tentang Pembentukan dan Pelaksanaan Tugas Tim Pengawal dan Pengaman Pemerintahan dan Pembangunan Kejaksaan Republik Indonesia 